definition in any part of the skeleton, is a more powerful source of X-rays; in other words, a step further in the preparation of Crookes' tubes. Even now the shadows obtained are good enough for many surgical purposes."

One of the most important discoveries in the new field of investigation is that certain phosphorescent substances emit rays capable of penetrating opaque materials and producing photographic effects. M. Henri Becquerel's experiments in connection with this matter have formed the subject of several valuable communications to the Paris Academy of Sciences, and have been referred to in our abstracts of the Comptes rendus, as well as in a brief note. We propose to give a full account of his work in a subsequent number of NATURE.

Mr. A. Hutchinson has sent us, under date March 23, the following account of experiments carried out by him in the Mineralogical Museum, Cambridge :-

"During the past few weeks I have found that quite a number of inorganic substances fluoresce when exposed to the action of the Röntgen rays; thus the following minerals all become more or less luminous, viz. diamond fluor-spar, apatite, autunite, scheelite, and a number of lead compounds, including cerussite, matlockite, anglesite, lanartrite, phosgenite ; also lead chloride, lead iodide, lead glass, uranium nitrate and uranium glass. The fluorescence produced in most of these substances is very weak, but autunite, uranium nitrate and uranium glass, cerrussite, some specimens of fluor spar, and some diamonds become fairly bright. The most effective substance which I have so far examined is, however, scheelite, the native tungstate of calcium. Colourless crystals of this mineral phosphoresce brilliantly under the action of the X-rays, the glow continuing for some seconds after the current is switched off, and when powdered they afford a screen which is at least as bright, if not brighter, than one prepared with barium platinum cyanide. It seems very possible that this substance may be 'the properly-crystallised' calcium tungstate of Edison's telegram, quoted in NATURE of March I9.

"It is, perhaps, interesting to note also that uranium nitrate, uranium glass, and the minerals autunite and torbernite are all capable of producing the remarkable effects discovered by $M$. Becquerel. Thus I have found that the radiations given out by uranium nitrate, when exposed to daylight, in an ordinary room are capable in twenty-four hours of penetrating sheets of aluminium $0.5 \mathrm{~mm}$. thick, and I have obtained a shadow photograph of a coin by placing it on a plate, thoroughly protected from sunlight by light-tight envelopes, and covering it with a slab of uranium glass. This arrangement was allowed to stand near a window for a day; on developing the plate a distinct outline of the coin was found."

A decided step in advance in the application of Röntgen photography to medical science is marked by illustrations in the current issues of the British Medical Tournal and the Lancet. The former journal contains a striking double-page plate of the skeleton of an infant, reproduced from a photograph by Mr. Sydney Rowland, and demonstrates at once the ability to portray the deep visceral region of the body by means of Röntgen rays. Mr. Rowland remarks that although no disease was present in the body of the child, the picture is none the less interesting from a scientific and medical point of view as being the first step towards the application of the method to the diagnosis of spinal and other deep affections. The photograph was obtained in fourteen minutes, and the age of the child was three months. The tube employed was the new focus tube, and it was placed some eight inches from the surface of the body so as to obtain sufficient spreading to cover the plate. It is pointed out that the positions of some of the soft organs are indicated on the picture ; thus the heart and lungs are clearly silhouetted, and curiously enough the coils of intestine; while a clear space above them exhibits the place occupied by the stomach. A striking feature is that only the ossified portions of the bones in the arm and hand produce definite shadows, the undeveloped parts of the bones being but faintly visible.

The Lancet referred in the issue of March 2I to a photograph obtained through the body of a dead monkey, into whose kidney a biliary and uric acid calculus had been previously inserted. The current issue contains a plate reproduced from this photograph, and showing the spinal column and ribs with great clear ness. The biliary calculus can hardly be distinguished from the kidney substance, but the uric acid calculus shows very clearly. The kidney itself is almost transparent to the rays, though not absolutely so.

In a letter communicated to the Electrician, Prof. G. M. Minchin gives a summary of the conclusions to which he has been led with reference to the discharge of electrified bodies by the X-rays. The generally accepted opinion is that the $\mathrm{X}$-rays discharge negative electricity from all bodies with great rapidity, and positive more slowly, leaving every body finally with a positive charge. Prof. Minchin, however, finds that "the X-rays charge some bodies positively and some negatively, and whatever charge a body may receive by other means, the $\mathrm{X}$-rays charge it, both in magnitude and sign, to the charge which they independently give to the body." While gold, silver, copper, platinum and iron are all charged positively by the X-radiation, sodium, magnesium, tin, lead and zinc are charged negatively, the effect being in the case of some of these metals much more marked than in the case of the metals that become positively charged. Antimony appears to be almost neutral. Prof. Minchin considers that these observations tend to support the view that the X-rays are undulatory in character, and not of the nature of kathode rays.

Prof. Oliver Lodge writes to the Times:- "It may be worth just putting on record that during the past week I have seen fluorescence excited by Röntgen rays after they had penetrated the bodies of two men standing one behind the other in their clothes. Also, that we have succeeding in radiographing the details of a damaged vertebra in the spine of an adult patient at the Northern Hospital, Liverpool, with an exposure of half an hour; and have found a 'Murphy-button' in the intestine of another adult at the Liverpool Royal Infirmary with an exposure of ten minutes. A 'focus.tube' and a powerful ordinary induction coil were the means used."

Six good photographic reproductions accompany an article on Röntgen photography contributed by Mr. J. W. Gifford to Knowledge. One of the pictures of a mouse, and another of a sparrow, obtained on February 28, clearly locate the internal organs.

Finally, a number of important papers are referred to in the abstract of the Comptes rendus which appears in another column.

\section{REPORT ON THE USE OF ANTITOXIN IN DIPHTHERIA.}

A DETAILED report on the use of antitoxic serum in diphtheria, at the hospitals of the Metropolitan Asylums Board, has just been issued. It exhibits the results obtained,during the year I895 in all the six hospitals in which cases of diphtheria were treated, and is a most valuable testimony to the efficacy of the new treatment. From the summary of the report given in the Times we derive the subjoined general statistical results and conclusions.

Antitoxin was administered in rather more than three-fifths of the total number of cases admitted into the hospitals, and those for the most part representing the severer types of disease. The value of results obtained will be seen by taking the whole of the figures for 1895 and contrasting them with those of 1894 , or rather with the first ten months of that year, previous to the introduction of antitoxin. This gives the following results :

\begin{tabular}{|c|c|c|c|c|c|c|}
\hline Year. & & Cases. & & Deaths. & & $\begin{array}{l}\text { Mortality } \\
\text { per cent. }\end{array}$ \\
\hline I 894 & $\cdots$ & 3042 & $\cdots$ & 902 & $\cdots$ & $29 \cdot 6$ \\
\hline 1895 & $\ldots$ & 3529 & $\ldots$ & 796 & ... & $22 \cdot 5$ \\
\hline
\end{tabular}

The reduction in mortality of $7 \cdot x$ per cent. below that of 1894-the lowest previously recorded in any year-must be fairly attributed to antitoxin, because nothing else was changed in the treatment; the average severity of the disease was about equal in the two years, and the proportion of juvenile, that is unfavourable, patients was somewhat larger in 1895 than in I894. It may be added that diphtheria in both years alike means diphtheria as clinically, not bacteriologically, diagnosed. The essential conditions, therefore, were the same in the two periods. Had antitoxin been used in all cases in 1895 , instead of in three-fifths only, the comparison would have been more symmetrical, but the numbers are sufficiently large to make it quite valid; and in this connection it is worth noting that those individual hospitals which made least use of the drug show the highest rate of mortality and the smallest reduction on their previous records. The broad conclusion reached is that in the year 1895 antitoxin saved 250 lives in London.

A complete examination and discussion of the statistics, leads to the following conclusions :-

The improved results in the diphtheria cases treated during the year 1895 , which are indicated by the foregoing statistics and clinical observations, are :- 
(1) A great reduction in the mortality of cases brought under treatment on the first and second day of illness.

(2) The lowering of the combined general mortality to a point below that of any former year.

(3) The still more remarkable reduction in the mortality of the laryngeal cases.

(4) The uniform improvement in the results of tracheotomy at each separate hospital.

(5) The beneficial effect produced on the clinical course of the disease.

A consideration of the foregoing statistical tables and clinical observations, covering a period of twelve months and embracing a large number of cases, sufficiently demonstrates the value of antitoxin in the treatment of diphtheria.

It must be clearly understood, however, that to obtain the largest measure of success with antitoxin it is essential that the patient be brought under its influence at a comparatively early date-if possible not later than the second day of disease. From this time onwards the chance of a successful issue will diminish in proportion to the length of time which has elapsed before treatment is commenced. This, though, doubtless, true of other methods, is of still greater moment in the case of treatment by antitoxin.

Certain secondary effects not infrequently arise as a direct result of the injection of antitoxin in the form in which it has at present to be administered, and, even assuming that the incidence of the normal complications of diphtheria is greater than can be accounted for by the increased number of recoveries, we have no hesitation in expressing the opinion that these drawbacks are insignificant when taken in conjunction with the lessened fatality which has been associated with the use of this remedy.

We are further of the opinion that in antitoxin serum we possess a remedy of distinctly greater value in the treatment of diphtheria than any other with which we are acquainted.

\section{UNIVERSITY AND EDUCATIONAL INTELLIGENCE.}

CAMBridge. - The next examination for the diploma in agricultural science and practice will begin on July 6,1896 . Names of candidates should be sent to the Registrary of the University on or before Monday, June 22, 1896 . The examination is open to persons who are not members of the University as we!l as to members.

WE learn from Science that the Bill establishing a National University of the United States has been reported favourably by the Senate Committee. It grants a charter to the University, provides for its government, grants it the ground in the city of Washington designated by President Washington as a site for a national university, and appropriates 15,000 dols. for the fiscal year ending on June 30, 1897, and 25,000 dols. for the year following.

WE offer our best wishes to Education, Secondary and Technical, the new weekly journal of combined educational interests, which has taken the place of the Technical World and Science and Art. There is much for such a periodical to do, and the combination of technical and secondary interests in education is certainly one that makes for advancement. As the journal is the official organ of the Incorporated Association of Head Masters, the Association of Directors and Organising Secretaries of County Councils, the National Association of Manual Training Teachers, and the Recreative Evening Schools Association, it should not lack support.

Aт a meeting of the Technical Education Board of the Stourbridge district, held on Tuesday, March 17, the Chairman announced that promises amounting to $£ 540$ had already been received towards the building fund for the proposed new technical schools in that town. Other promises, where the actual amount has not been specified, will materially increase this total. The sum at present assured enables the Committee to claim a grant of $£ 600$ from the Worcestershire County Council. It is not intended that a site should be chosen and active steps taken until the sum of $£ 2000$ is in hand.

AT the meeting of the Association of Chambers of Commerce, held at the Hôtel Métropole, London, on Wednesday, the 25th ult., the following resolution, proposed by the London Chamber, was agreed to:- "That this association views with interest the report of the Royal Commission on Secondary Education, and, while it regrets the exclusion of commercial representation from its membership, suggests that its recommendations be carefully considered, and, so far as they commend themselves, put into practice at an early a date as possible. That the Executive Council be recommended to take an early opportunity of urging upon Chambers of Commerce the necessity of keeping in touch with their local County Councils, in order that such Chambers may secure representation upon any local educational authority which may be called into existence by legislation, and thus obtain the due consideration and provision of industrial and commercial education recognised by the Royal Commission as falling under secondary education."

THE Paris correspondent of the British Medical Journal reports that the French Senate is about to name a Commission to examine the New University Law, which has been voted unanimously by the Lower Chamber. In the last bulletin of the Minister of Public Instruction of grants, receipts, and register of students in the French faculties during the ten years 1884 to 1895 , it is stated that in 1884 a total of 14,000 students were registered in the different faculties, and in 189524,000 . In I 884 Government granted to the faculties $£ 460$,000. In ten years $£ 104,000$ has been added, making a total of $£ 564,000$. The faculties received from students' fees ten years ago very nearly $£ \mathrm{I} 60,000$, and last year a little more than $£ 260,000$. In I 884 each university student cost $£_{21}$ I $8 s$. $4 d$. In consequence of the considerable afflux of pupils, the cost to the university for each student is now $£$ I I os. Iod. The French universities consider that Government does not treat them with sufficient liberality. In support of their plea the grants to the German universities are quoted; these are $£ 400,000$ more than the amount granted by the French Government. No hope is entertained that by Government help the French universities will rival the German universities in organisation of laboratories, libraries, and general excellence.

A strong Committee has been formed to organise some permanent memorial to perpetuate the memory of the late Rev. William Rogers, who did good pioneer work for education. It is proposed that the funds obtained should be used in connection with the St. Thomas, Charterhouse Schools, where Mr. Rogers worked to improve middle-class education, and assisted to develop the present system of elementary education. The introduction into primary schools of the practical study of science and art was commenced there. Dr. Gladstone, F.R.S., in giving evidence before a Special Committee of the London School Board, once said :- "Prof. Sylvanus Thompson told me that the only elementary school in London from which the Finsbury College could draw youths qualified for technical classes, was that of St. Thomas, Charterhouse, where a good deal of scientific instruction is given, and the boys are encouraged to make their own apparatus." The great aim has been to make the institution self-supporting, and this to a great extent has been accomplished ; but the providing of special and costly science apparatus-of effecting expensive structural alterations-render it necessary to occasionally apply for extraneous aid, so that Mr. Rogers' work may not be allowed to languish. The late founder, before his serious accident, was intent upon helping the School Committtee to raise funds by means of which the building could be modernised, and a play. ground added, and additional science accommodation provided. Subscriptions for these purposes, made payable to the account of the Rogers Memorial Fund, will be gladly received by either of the Hon. Secretaries, St. Thomas, Charterhouse Schools, Goswell Road, London, E.C.

Sir JoHn Gorst introduced the Education Bill of the Government into the House of Commons on Tuesday. The Bill is a great measure of educational decentralisation. It provides for the establishment of a paramount educational authority in every county and county borough. This is to be the channel through which public money is to reach the schools. It is to supplement and not to supersede existing educational effort, and it is to be a sort of separate Education Department for each county and county borough. Sir John Gorst also proposes that the educa* tion authority shall be the county council acting through a statutory educational committee, and the number and composition of this committee is to be left entirely in the discretion of the county council, subject only to the condition that the majority of its members must be also members of the council. The in-

No. I379, voL. 5.3] 